\title{
Gambaran Persepsi Remaja Terhadap Perilaku Lesbian, Gay, Biseksual dan Transgender (LGBT) di SMAN 1 Tamansari Kabupaten Bogor
}

\author{
Warsina Wati ${ }^{1)}$, Subandi2) \\ Email : warsinawati104@gmail.com \\ Program Studi Keperawatan Bogor Poltekkes Bandung
}

\begin{abstract}
ABSTRAK : Perilaku Lesbian, Gay, Biseksual dan Transgender (LGBT) adalah suatu bentuk perilaku negatif, karena perilaku tersebut di pandang tidak sesuai dengan norma yang berlaku di masyarakat. Kelompok rentan terjangkitnya fenomena ini adalah dikalangan remaja. Oleh karena itu penting mengetahui persepsi remaja terhadap perilaku LGBT. Mengingat pentingnya masalah tersebut maka peneliti tertarik untuk meneliti tentang gambaran persepsi remaja terhadap perilaku LGBT. Tujuan penelitian ini adalah untuk mengetahui gambaran persepsi remaja terhadap perilaku Lesbian, Gay, Biseksual dan Transgender (LGBT. Desain penelitian ini adalah penelitian deskriptif. Populasi penelitian adalah siswi kelas 1 dan 2 SMAN 1 Tamansari Kabupaten Bogor. Cara pengambilan sampel dengan menggunakan proportional random sampling dengan target 87 responden, selanjutnya pengumpulan data diperoleh melalui instrument penelitian berupa kuesioner yang berjumlah 17 pernyataan dengan menggunakan skala Likert. Hasil penelitian ini, didapatkan sebagian besar (97\%) usia responden atau sebanyak 84 responden berusia antara 15-17 tahun. Dari seluruh responden lebih dari setengahnya (61\%) atau sebanyak 53 responden berjenis kelamin perempuan. Dari 87 responden lebih dari setengahnya yaitu 49 responden (56\%) memiliki persepsi yang positif dan menganggap LGBT adalah perilaku yang salah/menyimpang. Diharapkan kepada peneliti selanjutnya untuk mengembangkan penelitian tentang pengetahuan dan sikap remaja terhadap perilaku LGBT juga tentang peranan orang tua dalam pencegahan perilaku LGBT.
\end{abstract}

Kata Kunci: Persepsi, Perilaku LGBT, Remaja

\section{Description of Perception Teenagers About Lesbian, Gay, Biseksual and Transgender (LGBT) in SMAN 1 Tamansari Kabupaten Bogor}

\begin{abstract}
Lesbian, Gay, Bisexual and Transgender (LGBT) is negative behavior, because these activitie are incompatible with the norm in the community. Vulnerable groups infected by this phenomenon is among teenagers. Because of that, is important to know perception of teenagers about LGBT. Given the importance of this issue, the researcher interested to research about the perception of teenagers about LGBT. The purpose of this research is to find a perception of teenagers about Lesbian, Gay, Bisexual and Transgender (LGBT). This research uses descriptive design. This research takes in grade1 and 2 SMAN1 Tamansari Kabupaten Bogor. How to take the sample by using proportional random sampling with 87 respondents, the data collection obtained through research instrument of the 17 statement were using is likert scale. The result of this research, obtained most (97\%) the age of respondents or 84 respondents were aged between 15-17 year. From all respondents more than half of respondent (61\%) or 53 respondents were women. From 87 respondents more than half of whom 49 respondents (56\%) have the positive and consider LGBT is wrongful behavior/ deviating. Expected to next researchers to develop research on knowledge and attitude teenagers about LGBT and also about the role of the older people in prevention LGBT.
\end{abstract}

Keywords: Perception, LGBT, Teenagers 


\section{PENDAHULUAN}

Belakangan ini Indonesia dihebohkan dengan isue Lesbian, Gay, Biseksual, dan Transgender (LGBT). Perilaku LGBT adalah suatu bentuk perilaku negatif karena perilaku tersebut di pandang tidak sesuai dengan norma yang berlaku di masyarakat. Perilaku-perilaku tersebut dikatakan suatu bentuk perilaku penyimpangan seksual karena tidak sesuai dengan orientasi seksual yang seharusnya. Saat ini lesbian sudah terang-terangan menampakan keberadaan mereka, bahkan bukan hanya lesbian saja yang terang-terangan menampakan keberadaan mereka, kaum gay, biseksual dan transgender juga sedikit banyak melakukan kegiatankegiatan yang membuat keberadaan mereka diketahui oleh masyarakat luas ${ }^{1}$.

Data yang di himpun Ketua Pelaksana Harian Komisi Penanggulangan Aids (KPA) Kota Bogor, jumlah kaum LGBT mencapai 900 orang. Rinciannya, golongan biseksual 311 orang, gay 235 orang dan transgender 38 orang. Populasi ini jumlahnya terus mengalami peningkatan seiring adanya fenomena pergeseran pandangan masyarakat Indonesia mengenai homoseksual.

Bahaya LGBT adala jika seseorang yang bergaul dengan orang-orang yang berperilaku menyimpang, maka lambat laun akan mengakibatkan dirinya ikut dalam arus penyimpangan itu sendiri khususnya bagi kelompok-kelompok rentan. Pada dasarnya pengertian mengenai kelompok rentan ${ }^{1}$. Dalam UU Nomor 39 Tahun 1999 pasal 5 ayat 3 dijelaskan bahwa setiap orang yang termasuk kelompok masyarakat yang rentan berhak memperoleh perlakuan dan perlindungan lebih berkenaan dengan kekhususannya. Kelompok rentan terjangkitnya fenomena ini adalah dikalangan remaja.

Remaja adalah untuk semua anak yang berusia 10 sampai 18 tahun $^{2}$. Pada masa ini terjadi masa pubertas yang akan dilalui berupa kematangan emosional maupun seksualitasnya. Oleh karena itu, remaja memerlukan penilaian kesehatan secara komprehensif untuk memastikan bahwa remaja dapat melewati masa pubertasnya dengan lancar. Maturasi seksual merupakan masalah penting lainnya selama remaja. Semua remaja harus dinilai derajat maturitas seksualnya. Pemantauan kemajuan derajat maturasi seksual merupakan komponen penting evaluasi proses pubertas yang telah berlangsung. Perubahan biologis, sosial dan kognitif selama masa remaja memiliki fokus pada perkembangan seksual. Merasa nyaman dengan satu jenis kelamin merupakan salah satu prinsip utama pada periode ini dan kemungkinan akan melibatkan berbagai pertanyaan dan eksperimen. Hampir setengah dari anak SMA pernah melakukan hubungan seksual. Sepuluh sampai $25 \%$ memiliki setidaknya satu kali pengalaman homoseksual. Meskipun banyak remaja memiliki pengalaman seksual dengan jenis kelamin yang sama, namun hanya sedikit sekali yang akhirnya memiliki orientasi seksual homoseksual. Ketika remaja mengembangkan orientasi seksual yang konsisten, hal tersebut mungkin dipengaruhi oleh berbagai faktor (sosial, keluarga, individu). Beberapa remaja melaporkan bahwa mereka yakin orientasi seksual mereka sejak usia remaja awal, sedangkan sisanya terjadi lebih lambat. Pada usia 18 tahun, hanya sebagian kecil remaja yang merasa tidak yakin akan orientasi seksual mereka.

Rata-rata seorang lesbian menyadari kehomoseksualannya sejak remaja ${ }^{3}$. Dalam penelitiannyapun ditemukan tiga faktor umum terbentuknya identitas seksual pada remaja. Faktor tersebut adalah adanya broken home yang lebih mengacu pada kekerasan dalam rumah tangga, selain itu adanya trauma terhadap kaum laki-laki dan juga yang terakhir adalah karena masuknya remaja tersebut 
kedalam suatu komunitas yang didalamnya terdapat remaja-remaja yang mengaku dirinya homoseksual. Pada masa remaja terdapat tahap perkembangan identity vs identity confusion dan hal itu dapat menyebabkan seorang remaja menjadi lesbian sebagai identitas seksualnya serta pada proses perkembangannya seorang remaja harus melalui proses pencapaian identitasnya. Selain itu, berada pada satu komunitas tertentu yang banyak remaja lesbi pun mempengaruhi proses pembentukan identitas sosialnya.

Persepsi masyarakat terkait perilaku penyimpangan seksual seperti transgender dianggap perilaku tersebut sebagai suatu perilaku yang menyimpang dari nilai-nilai sosial yang dianut oleh masyarakat ${ }^{4}$. Terkait masalah perilaku LGBT, kiranya kitapun harus mengetahui persepsi tiap individu remaja mengenai kelainan seksual tersebut. Hal tersebut di karenakan persepsi remaja terhadap LGBT akan menggambarkan pemikiran dan gambaran mereka khususnya terhadap LGBT dan umumnya terhadap pemahaman identitas gender dan orientasi seksual.

Dari hasil studi pendahuluan yang telah dilakukan, penulis akhirnya memilih SMAN 1 Tamansari Kabupaten Bogor sebagai tempat penelitian karena di SMA tersebut sebelumnya belum pernah dilakukan penelitian seperti yang penulis lakukan. Oleh karena itu, dari uraian di atas penulis tertarik untuk melakukan penelitian sederhana mengenai "Gambaran Persepsi Remaja Terhadap Perilaku Lesbi, Gay, Biseksual dan Transgender (LGBT) di SMAN 1 Tamansari Kabupaten Bogor".

Penelitian ini bertujuan untuk mengetahui gambaran persepsi remaja terhadap perilaku Lesbian, Gay, Biseksual dan Transgender (LGBT) di SMAN 1 Tamansari Kabupaten Bogor.

\section{METODE}

Penelitian ini menggunakan design penelitian deskriptif. Penelitian ini dilaksanakan oleh peneliti di SMAN 1 Tamansari Kabupaten Bogor. Pada penelitian ini yang dijadikan populasi adalah siswa/siswi kelas 10 dan kelas 11, yaitu sebanyak 660 siswa. Cara pengambilan sampel dengan menggunakan proportional random sampling dengan target 87 responden.

Kriteria sampel yang dibutuhkan secara inklusi yaitu remaja yang masih tercatat sebagai siswa di SMAN 1 Tamansari, remaja yang mendapatkan izin dari pihak sekolah dan remaja yang bersedia di jadikan responden. Adapun kriteria secara ekslusi yaitu remaja yang izin atau tidak ada di tempat saat pengumpulan data dan remaja yang saat pengumpulan data sedang sakit.

Teknik pengumpulan data dalam penelitian ini adalah menggunakan teknik angket dengan bentuk pernyataan yang terstruktur melalui kuesioner. Adapun pengolahan dan analisis data dalam penelitian ini sebagai berikut:

1. Editing (Penyuntingan Data)

Hasil angket yang diperoleh atau dikumpulkan melalui kuesioner disunting terlebih dahulu. Jika ternyata masih ada data atau informasi yang tidak lengkap, dan tidak mungkin dilakukan wawancara ulang, maka kuesioner tersebut dikeluarkan (drop out)

\section{Coding}

Dalam kuesioner $\mathrm{A}$, pada bagian umur diberi kode 1 untuk usia 11-14 tahun, kode 2 untuk usia 15-17 tahun dan kode 3 untuk usia 18-20 tahun. Pada bagian jenis kelamin diberi kode 1 untuk laki-laki dan kode 2 untuk perempuan.

Dalam kuesioner B kode untuk pernyataan positif (soal no 1, 2, 5, 7, 8, 12, 13 , 15, dan 16) sangat setuju: 4 , setuju: 3 , tidak setuju: 2, sangat tidak setuju: 1 . Untuk pernyataan negatif (soal no 3, 4, 6, $9,10,11,14$, dan 17) sangat setuju: 1, 
setuju: 2, tidak setuju: 3, sangat tidak setuju: 4.

Analisa yang digunakan peneliti adalah analisis univariat. Karakteristik yang dianalisis antara lain: usia dan jenis kelamin. Untuk variabel persepsi menggunakan skala likert dan diinterpretasikan berdasarkan distrubusi ferekuensi nilai mean atau median. Persepsi positif bila hasil skor $\geq 57,82$ dan persepsi negatif bila hasil skor $<57,82$.

\section{HASIL}

\section{a. Usia}

Diagram 5.1

Distribusi Frekuensi Responden Berdasarkan Usia pada Remaja di SMAN 1 Tamansari Kabupaten Bogor tahun 2017( $n=87$ )

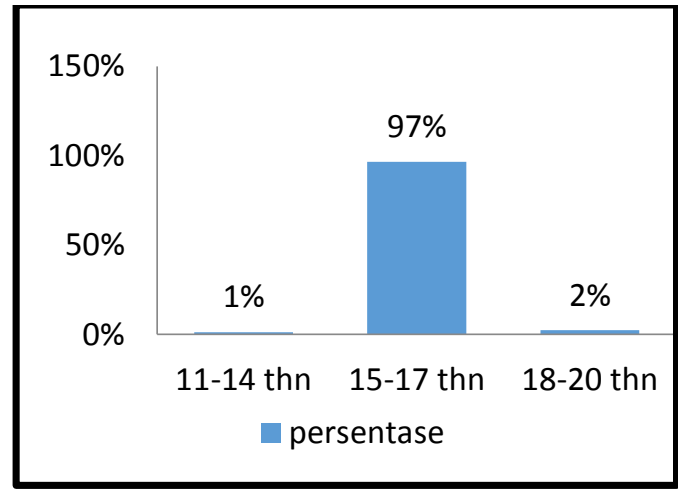

Berdasarkan Diagram 5.1 diatas dapat dilihat bahwa usia responden sebagian besar (97\%) atau sebanyak 84 responden berusia antara 15-17 tahun.

\section{b. Jenis Kelamin}

Diagram 5.2

Distribusi Frekuensi Responden Berdasarkan Jenis Kelamin pada Remaja di SMAN 1 Tamansari Kabupaten Bogor tahun 2017( $n=87$ )

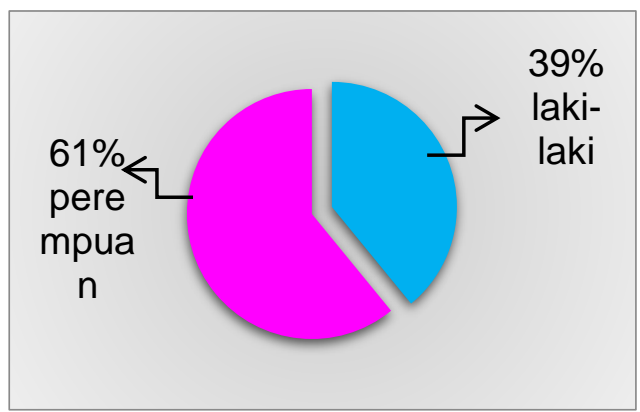

Berdasarkan Diagram 5.2 diatas dapat dilihat bahwa dari seluruh responden, lebih dari setengahnya $(61 \%)$ atau sebanyak 53 responden berjenis kelamin perempuan.

\section{c. Gambaran Persepsi Remaja}

Diagram 5.3

Distribusi Frekuensi Persepsi Remaja Terhadap Perilaku Lesbian, Gay, Biseksual dan Transgender (LGBT) di SMAN 1 Tamansari Kabupaten Bogor tahun 2017 ( $n=87$ )

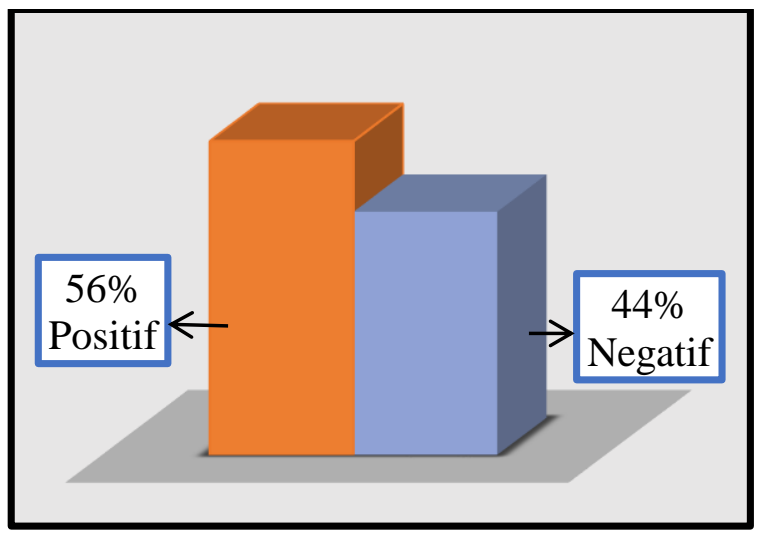

Berdasarkan Diagram 5.3 diatas menunjukkan bahwa dari seluruh responden, dapat disimpulkan lebih dari setengahnya (56\%) atau sebanyak 49 responden memiliki persepsi yang positif dan menganggap bahwa LGBT adalah perilaku yang salah/ menyimpang. 
d. Persepsi Remaja Terhadap Perilaku LGBT di SMAN 1 Tamansari Berdasarkan Karakteristik

Tabel 5.1

Persepsi Remaja Terhadap Perilaku Lesbian, Gay, Biseksual dan Transgender (LGBT) di SMAN 1 Tamansari Kabupaten Bogor tahun 2017 Berdasarkan Karakteristik $(n=87)$

\begin{tabular}{|l|c|c|c|c|}
\hline \multirow{2}{*}{ Karakteristik } & \multicolumn{2}{|c|}{$\begin{array}{c}\text { Persepsi } \\
\text { Positif }\end{array}$} & \multicolumn{2}{c|}{$\begin{array}{c}\text { Persepsi } \\
\text { Negatif }\end{array}$} \\
\cline { 2 - 5 } & $\mathbf{n}$ & $\mathbf{\%}$ & $\mathbf{n}$ & $\%$ \\
\hline $\begin{array}{c}\text { Jenis } \\
\text { Kelamin }\end{array}$ & & & & \\
\hline Laki-laki & 20 & $23 \%$ & 14 & $16 \%$ \\
\hline Perempuan & 29 & $33 \%$ & 24 & $28 \%$ \\
\hline Jumlah & $\mathbf{4 9}$ & & $\mathbf{5 2}$ & \\
\hline Usia & & & & \\
\hline 11-14 Tahun & 0 & $0 \%$ & 1 & $1 \%$ \\
\hline 15-17 Tahun & 49 & $56 \%$ & 35 & $41 \%$ \\
\hline 18-20 Tahun & 0 & $0 \%$ & 2 & $2 \%$ \\
\hline Jumlah & $\mathbf{4 9}$ & & $\mathbf{3 8}$ & \\
\hline
\end{tabular}

Berdasarkan Tabel 5.1 diatas dapat disimpulkan bahwa dari 87 responden berdasarkan jenis kelamin yang memiliki persepsi positif lebih banyak berjenis kelamin perempuan sebanyak 29 responden (33\%) dan berdasarkan usia yang memiliki persepsi positif berusia 1517 tahun sebanyak 49 responden (56\%).

\section{PEMBAHASAN}

Berdasarkan penelitian yang telah dilaksanakan diperoleh hasil bahwa lebih dari setengahnya (56\%) atau sebanyak 49 responden memiliki persepsi yang positif yang menganggap bahwa LGBT adalah perilaku yang salah/ menyimpang.

Persepsi masyarakat terkait perilaku penyimpangan seksual seperti transgender dianggap perilaku tersebut sebagai suatu perilaku yang menyimpang dari nilai-nilai sosial yang dianut oleh masyarakat ${ }^{4}$. Masyarakat pun sangat tidak setuju dengan perkawinan sejenis karena perilaku perkawinan sejenis merupakan suatu perilaku yang menyimpang dari norma agama dan norma sosial di dalam masyarakat sehingga perilaku ini masih dianggap sebagai suatu perilaku yang dianggap tabu di dalam masyarakat.

Hasil analisis persepsi dapat disimpulkan bahwa ada beberapa faktor yang mempengaruhi kesesuaian dalam mempengaruhi persepsi. Kesesuain ini terjadi antara hasil penelitian dengan konsep teori yang ada. Salah satu faktor yang mempengaruhi persepsi adalah pengalaman dan pengetahuan. Hal ini dengan teori bahwa pengalaman yang dimiliki seseorang merupakan faktor yang sangat berperan dalam menginterpretasikan stimulus yang diperoleh. Pengalaman masa lalu atau apa yang telah dipelajari akan menyebabkan terjadinya perbedaan interpretasi $i^{5}$.

Dalam penelitian ini pengalaman dan pengetahuan bersumber dari rentang usia responden. Hampir setengahnya yaitu sebanyak 49 responden (56\%) berusia 15-17 tahun memiliki persepsi yang positif yaitu menganggap bahwa LGBT adalah perilaku yang salah atau menyimpang. Masa remaja pertengahan (15-17 tahun) ini remaja mengalami perkembangan kemampuan untuk berfikir abstrak atau kemampuan menemukan pemecahan masalah tanpa hadirnya permasalahan itu secara nyata ${ }^{6}$. Perkembangan kognitif pada masa remaja pun mencapai puncaknya pada kemampuan berpikir abstrak. 
Selain itu faktor lain yang mempengaruhi persepsi adalah emosi. Emosi seseorang akan mempengaruhi persepsinya terhadap stimulus yang ada ${ }^{5}$. Pada penelitian ini emosi dapat dilihat dari karakteristik jenis kelamin responden. Dalam penelitian ini yang memiliki persepsi positif lebih banyak berjenis kelamin perempuan sebanyak (33\%) atau sebanyak 29 responden. Perempuan memiliki kemampuan lebih baik untuk meningkatkan kecerdasan emosional dibandingkan dengan laki-laki. Anak perempuan lebih cepat terampil berbahasa daripada anak laki-laki, maka mereka lebih berpengalaman dalam mengutarakan perasaan dan lebih cakap daripada laki-laki dalam memanfaatkan kata-kata untuk menjelajahi dan untuk menggantikan reaksi-reaksi emosional seperti perkelahian fisik. Sebaliknya sebagian besar laki-laki tampak kurang peka akan keadaan emosinya, baik dalam dirinya sendiri maupun dalam diri orang lain ${ }^{7}$. Pada umumnya laki-laki lebih berkembang dalam hal perasaan jati diri dan kemampuan dalam menghadapi kesulitan sedangkan pada perempuan lebih berkembang dalam hal hubungan antar sesama, tanggung jawab sosial dan empati dengan orang lain ${ }^{8}$.

Faktor lain yang mempengaruhi persepsi yaitu budaya. Namun pada penelitian ini peneliti tidak mengukur mengenai budaya. Diharapkan untuk penelitian selanjutnya jika meneliti kembali mengenai persepsi, agar mengukur budaya karena karena seseorang dengan latar belakang budaya yang sama akan menginterpretasikan orang-orang dalam kelompoknya secara berbeda, namun akan mempersepsikan orang-orang diluar kelompoknya sebagai sama saja ${ }^{5}$. Budaya atau adat istiadat dapat memengaruhi tumbuh kembang anak-anak. Tak terkecuali budaya yang mengarah pada pembentukan orientasi seksual sesama jenis ${ }^{9}$.

\section{SIMPULAN}

1. Karakteristik responden sebagian besar berusia 15-17 tahun dan lebih dari setengahnya berjenis kelamin perempuan.

2. Persepsi remaja terhadap perilaku LGBT didapatkan data lebih dari setengahnya memiliki persepsi yang positif dan menganggap bahwa LGBT adalah perilaku yang salah/ menyimpang.

3. Persepsi berdasarkan karakteristik didapatkan data bahwa berdasarkan jenis kelamin yang memiliki persepsi positif lebih banyak berjenis kelamin perempuan dan berdasarkan usia yang memiliki persepsi positif berusia 15-17 tahun.

\section{DAFTAR PUSTAKA}

1. Budiarty, Astry (2011), Gaya Hidup Lesbian (Kasus di Kota Makasar), skripsi dipublikasikan, Universitas Hasanuddin, Makassar.

2. Marcdante, Karen J dkk.2011. Nelson IImu Kesehatan Anak Esensial. Jakarta: Saunders Elsevier

3. Faridatunnisa, Ayu (2010). Gambaran Status Identitas Remaja Puteri Lesbi. Jurnal Psikologi Volume 8 Nomor 2, Desember 2010.

4. Jasruddin, Nurdelia, dkk (2016). Transgender Dalam Persepsi Masyarakat. Jurnal Equilibrium FKIP Unismuh Makassar, Volume II No. 1 Januari 2016 
5. Notoatmodjo, S. 2010. Metodologi Penelitian Kesehatan. Jakarta: Rineka Cipta.

6. Wong, D. L. (2009). Buku Ajar Keperawatan Pediatrik. Jakarta: EGC

7. Goleman, Daniel. 2015. Emotional Intelligance: Kecerdasan Emosional. Mengapa EI Lebih Penting Daripada IQ.
Jakarta: Gramedia Pustaka Utama.

8. Mubayidh, M. 2007. Kecerdasan dan Kesehatan Emosional Anak. Jakarta: Pustaka Al-Kautsar

9. Sinyo. 2014. Anakku Bertanya Tentang LGBT. Jakarta: PT Elex Media Komputindo 